\title{
NG2 Cells in White Matter But Not Gray Matter Proliferate in Response to PDGF
}

\author{
Robert A. Hill, ${ }^{1}$ Kiran D. Patel, ${ }^{1}$ Jelena Medved, ${ }^{1}$ Alex M. Reiss, ${ }^{1}$ and Akiko Nishiyama ${ }^{1,2}$ \\ ${ }^{1}$ Department of Physiology and Neurobiology, University of Connecticut, Storrs, Connecticut 06269, and ${ }^{2}$ University of Connecticut Stem Cell Institute, \\ Farmington, Connecticut 06230
}

Glial cells that express the NG2 proteoglycan and the $\alpha$ receptor for PDGF (NG2 cells, polydendrocytes) make up the fifth major cell population that serves as oligodendrocyte progenitor cells in the postnatal CNS. Although recent studies have suggested differences in their proliferation and oligodendrocyte differentiation in gray and white matter, the mechanism underlying the observed differences has been unclear. Using organotypic slice cultures from the forebrain and cerebellum of early postnatal NG2creBAC:ZEG mice, we have compared basal and growth factor-induced proliferation of NG2 cells in gray and white matter. NG2 cells in white matter exhibited greater proliferative response to PDGF AA than those in gray matter. Heterotopic slice transplant and explant cultures suggested intrinsic mechanisms for the differential proliferative response of gray and white matter cells. Additionally, younger white matter NG2 cells showed a more robust proliferative response to PDGF. Basal and PDGF-induced proliferation of gray and white matter NG2 cells was largely dependent on Wnt/ $\beta$-catenin and phosphatidylinositol 3-kinase acting through the mammalian target of rapamycin pathway and not through ERK. These data uncover a previously unrecognized divergence between gray and white matter NG2 cells in the developing brain in their proliferative response to PDGF.

\section{Introduction}

Cells that express the NG2 chondroitin sulfate proteoglycan (NG2 cells) make up a unique glial cell population in the CNS (Nishiyama et al., 2009). They are the source of myelinating oligodendrocytes, comprise $\sim 70 \%$ of cycling cells in the CNS, and persist uniformly in gray and white matter throughout development and adulthood (Dawson et al., 2003; Nishiyama et al., 2009). It has been debated whether NG2 cells comprise a functionally homogeneous cell population or whether they represent a heterogeneous population with distinct properties. Differences in the behavior of NG2 cells in gray and white matter have been observed. For example, NG2 cells in the corpus callosum proliferate and differentiate into oligodendrocytes at a greater rate than those in the neocortex (Dawson et al., 2003; Dimou et al., 2008; Rivers et al., 2008; Kang et al., 2010; Zhu et al., 2011). Neocortical NG2 cells have more hyperpolarized resting membrane potentials and greater inwardly rectifying potassium channel currents compared with those in the corpus callosum (Chittajallu et al., 2004). Furthermore, recent studies on multiple sclerosis (MS) lesions have revealed differences in the pathology and the extent

Received April 24, 2012; revised June 26, 2013; accepted July 31, 2013.

Author contributions: R.A.H., K.D.P., and A.N. designed research; R.A.H., K.D.P., J.M., A.M.R., and A.N. performed research; R.A.H. and A.N. contributed unpublished reagents/analytic tools; R.A.H., K.D.P., A.M.R., and A.N. analyzed data; R.A.H. and A.N. wrote the paper.

This work was supported by the National Multiple Sclerosis Society (A.N.), the National Institutes of Health (A.N.), and the National Science Foundation (A.N.). We thank Youfen Sun for assistance in maintaining the transgenic mouse colony and Dr. Hitoshi Gotoh for many helpful discussions.

The authors declare no competing financial interests.

Correspondence should be addressed to Dr. Akiko Nishiyama, Department of Physiology and Neurobiology, University of Connecticut, 75 North Eagleville Road, Storrs, CT 06269. E-mail: akiko.nishiyama@uconn.edu.

R. A. Hill's present address: Yale University School of Medicine, Department of Neurology, New Haven, СT 06511. DOI:10.1523/JNEUROSCI.2001-12.2013

Copyright $\odot 2013$ the authors $\quad 0270-6474 / 13 / 3314558-09 \$ 15.00 / 0$ of repair between gray and white matter (Albert et al., 2007; Stadelmann et al., 2008).

PDGF AA activates the $\alpha$ receptor (PDGFR $\alpha$ ) on NG2 cells and plays a critical role in regulating their proliferation and survival (Noble et al., 1988; Raff et al., 1988; Richardson et al., 1988; Barres et al., 1993). In the absence of PDGF, NG2 cells fail to develop in the spinal cord and cerebellum, resulting in hypomyelination. Transgenic overexpression of PDGF causes a dosedependent increase in NG2 cell proliferation in the developing spinal cord (Calver et al., 1998; Fruttiger et al., 1999).

Using organotypic slice cultures, which preserve tissue cytoarchitecture, we have found that NG2 cells in white matter undergo a greater proliferative response to PDGF than those in gray matter, despite similar levels of PDGFR $\alpha$ expression. Furthermore, we found that both basal and PDGF-induced NG2 cell proliferation is mediated primarily by phosphatidylinositol-3kinase $(\mathrm{PI} 3 \mathrm{~K})$ acting through the mammalian target of rapamycin (mTOR) pathway in combination with $\mathrm{Wnt} / \beta$-catenin signaling and not by the ERK pathway.

\section{Materials and Methods}

Animals. Postnatal day 4 (P4) and P8 male and female NG2creBAC:ZEG double transgenic mice and wild-type littermates (Zhu et al., 2008) were used. Z/EG mice (Novak et al., 2000) were maintained as homozygotes and bred to heterozygous female NG2creBAC animals (The Jackson Laboratory; stock 008533). All animal procedures were approved by the Institutional Animal Care and Use Committee at the University of Connecticut.

Slice culture. Cortical and cerebellar organotypic slice cultures were prepared from P4 and P8 NG2creBAC:ZEG double transgenic mice as described previously (Bahr et al., 1995, Zhu et al., 2011). Briefly, $300 \mu \mathrm{m}$ coronal forebrain or sagittal cerebellar slices were cut with a tissue chopper, separated in ice-cold dissection medium, and placed on Millicell culture inserts with $0.45 \mu \mathrm{m}$ pore size (Millipore). Slices were main- 
tained in a humidified $37^{\circ} \mathrm{C}, 5 \% \mathrm{CO}_{2}$ incubator. Slice media contained 50\% Minimal Essential Medium with Earle's Salts; 25 mм HEPES buffer, pH 7.22; 25\% HBSS without calcium chloride, magnesium chloride, or magnesium sulfate; $25 \%$ horse serum; $0.4 \mathrm{~mm}$ ascorbic acid; $1 \mathrm{~mm} \mathrm{L-glu-}$ tamine; and $1 \mathrm{mg} / \mathrm{L}$ insulin. Culture medium was changed $24 \mathrm{~h}$ after dissection and every other day thereafter.

Transplant experiments in slices were performed by micro-dissecting out $300 \mu \mathrm{m}^{3}$ blocks of tissue from either somatosensory cortex or corpus callosum out of slices from P8 NG2creBAC:ZEG mice and placing them on the somatosensory cortex or corpus callosum regions of wild-type littermate slice cultures prepared immediately before explant dissection. For isolated explant cultures, $300 \mu \mathrm{m}^{3}$ blocks from the somatosensory cortex and corpus callosum were placed directly on Millicell inserts.

Growth factor and inhibitor treatment. After $7 \mathrm{~d}$ in vitro (DIV), the cultures were exposed to growth factors and/or inhibitors of intracellular signaling pathways for $48 \mathrm{~h}$. Growth factors used included human PDGF AA (R\&D Systems), fibroblast growth factor 2 (FGF2, Invitrogen), and epidermal growth factor (EGF; R\&D Systems). Pharmacological agents used included inhibitors of PI3K, LY294002, and wortmannin; inhibitors of ERK 1/2, UO126, and PD98059; inhibitor of tankyrase XAV939, which inhibits $\beta$-catenin by stabilizing axin (Huang et al., 2009); and inhibitor of mTOR, rapamycin (all from Sigma). During the last $4 \mathrm{~h}$ of growth factor treatment, 5-ethynyl-2'-deoxyuridine (EDU) (Invitrogen) was added to the culture medium at a final concentration of $10 \mu \mathrm{M}$ to label cells undergoing DNA synthesis.

Tissue processing and immunohistochemistry. Slice cultures were fixed with $4 \%$ paraformaldehyde containing $0.1 \mathrm{M} \mathrm{L}$-lysine and $0.01 \mathrm{~m}$ sodium meta-periodate (PLP) for $30 \mathrm{~min}$ at room temperature followed by two washes in $0.2 \mathrm{M}$ sodium phosphate buffer, $\mathrm{pH}$ 7.0. For immunohistochemistry, slices were washed in PBS, permeabilized and blocked with $0.1 \%$ Triton X-100 and 5\% normal goat serum (NGS) in PBS for $1 \mathrm{~h}$, and then incubated at $4^{\circ} \mathrm{C}$ overnight with primary antibodies diluted in PBS containing 5\% NGS. Primary antibodies used were rabbit anti-NG2 (Millipore Bioscience Research Reagents; 1:500), chicken anti-green fluorescent protein (GFP, Aves Laboratories; 1:500), rabbit anti-PDGFR $\alpha$ (Dr. William Stallcup, Burnham Institute, La Jolla CA; 1:1000), goat anti-mouse PDGFR $\alpha$ (R\&D Systems; 1:2000), and mouse anti-myelin basic protein (MBP, SMI99, Sternberger Monoclonals; 1:2000) antibodies. After PBS wash, slices were incubated in secondary antibodies at room temperature for $1 \mathrm{~h}$ in PBS containing 5\% NGS. Secondary antibodies used were Alexa Fluor 488-conjugated antibodies (Invitrogen, 1:500), Cy3-conjugated antibodies (Jackson ImmunoResearch Laboratories; 1:500), and DyLight 649-conjugated antibodies (Jackson ImmunoResearch Laboratories; 1:200). Detection of EDU was performed after PBS wash according to the manufacturer's protocol. Slices were then mounted on glass slides in Vectashield mounting medium (Vector Laboratories) containing 4',6-diamidino-2-phenylindole (DAPI).

Fluorescence microscopy and quantification. Fluorescence images were captured on a Zeiss Axiovert 200M microscope with an ORCA ER camera (Hamamatsu) and Apotome grid confocal system (Zeiss), Leica TCS SP2 confocal microscope, or a Leica DMR upright fluorescence microscope equipped with an ORCA camera (Hamamatsu) using IPLab software. Images were processed in Adobe Photoshop (Adobe Photo Systems) and ImageJ (National Institutes of Health). Image manipulations were limited to gray-scale level adjustment. The proportion of proliferating NG2 cells was determined by counting the number of $\mathrm{GFP}^{+}$and $\mathrm{GFP}^{+} \mathrm{EDU}^{+}$cells in randomly selected gray and white matter regions identified by their location within the slice and by the distribution of myelin basic protein (see Figs. $1 \mathrm{~J}, \mathrm{~K}$ and 3 ). Data were collected from at least three mice. All values are expressed as means with SDs.

Fluorescence intensity measurements were performed as previously described (Hill et al., 2011) on coronal forebrain sections from P9 wildtype mice perfused with 4\% PFA-PLP and stained with different concentrations of anti-PDGFR $\alpha$ antibody (see Fig. 2). Images were captured with the same exposure settings, and mean fluorescence intensity values were determined per defined area using ImageJ followed by background intensity subtraction.
Western blots. After 5 DIV, cultures were exposed to inhibitors for $1 \mathrm{~h}$ before $30 \mathrm{~min}$ of stimulation with PDGF. Tissue was lysed in $50 \mathrm{~mm}$ Tris- $\mathrm{HCl}, \mathrm{pH} 7.4,150 \mathrm{~mm} \mathrm{NaCl}, 0.5 \%$ Nonidet P-40, 0.5\% sodium deoxycholate, $1 \%$ Triton X-100, $1 \mathrm{~mm}$ sodium orthovanadate, $1 \times$ protease inhibitor mixture (Sigma), and $1 \times$ PhosStop phosphatase inhibitor mixture (Roche) for $10 \mathrm{~min}$ on ice and sonicated. Protein concentration was determined by the detergent-compatible Lowry assay (Dc assay, Bio$\mathrm{Rad})$. Equal amounts of protein were heat denatured for $10 \mathrm{~min}$ under reducing conditions (62.5 mu Tris- $\mathrm{HCl}, \mathrm{pH} 6.8,2 \% \mathrm{SDS}, 10 \%$ glycerol, 100 mм DTT), separated by SDS-PAGE using $8 \%$ or $8-16 \%$ gradient acrylamide gels (Novex), transferred to polyvinylidene difluoride membranes (Millipore), and blocked for $1 \mathrm{~h}$ in blocking buffer consisting of 20 mм Tris- $\mathrm{HCl}, \mathrm{pH} 7.4,500 \mathrm{~mm} \mathrm{NaCl}, 5 \%$ BSA at room temperature. Membranes were incubated overnight at $4^{\circ} \mathrm{C}$ in blocking buffer containing antibodies to phospho-AKT Ser 473, total AKT, phospho-p44/42 MAPK (ERK1/2; Thr 202 Tyr 304), total p44/42 MAPK (ERK1/2) (all rabbit antibodies from Cell Signaling Technology, 1:1000), followed by incubation with goat anti-rabbit IRDye 800CW (LI-COR 1:10,000) in blocking buffer and imaged on an Odyssey IR scanner (LI-COR). Intensity of the bands was measured using the LI-COR software or ImageJ, and the intensity of phospho-specific bands were normalized to the intensity of the respective total protein bands.

\section{Results \\ White matter NG2 cells undergo greater PDGF-induced proliferation than gray matter NG2 cells}

To compare proliferation of NG2 cells in gray and white matter in response to growth factors, slice cultures from P8 NG2creBAC: ZEG forebrain were incubated with $10,25,50,100$, and $200 \mathrm{ng} / \mathrm{ml}$ PDGF or $50 \mathrm{ng} / \mathrm{ml} \mathrm{FGF2} \mathrm{or} \mathrm{EGF} \mathrm{and} \mathrm{labeled} \mathrm{with} \mathrm{EDU} \mathrm{during} \mathrm{the}$ last $4 \mathrm{~h}$ of culture. In NG2creBAC:ZEG double transgenic mice, NG2 cells and their progeny expressed GFP. Although vascular pericytes were also labeled with GFP in these mice, the cells we analyzed coexpressed NG2 and PDGFR $\alpha$ and had the morphology of NG2 cells. Basal levels of proliferation of NG2 cells in the gray and white matter were similar (Fig. 1E). Treatment with 50 $\mathrm{ng} / \mathrm{ml}$ PDGF resulted in a threefold increase in the proportion of $\mathrm{GFP}^{+}$cells that were $\mathrm{EDU}^{+}$in the region corresponding to the corpus callosum (white matter) (Fig. $1 A, B, E-I$ ). Treatment of the slices with 100 or $200 \mathrm{ng} / \mathrm{ml}$ PDGF did not elicit a significantly greater proliferative response compared with slices treated with $50 \mathrm{ng} / \mathrm{ml}$ PDGF $(50 \mathrm{ng} / \mathrm{ml}$ vs $100 \mathrm{ng} / \mathrm{ml} p=0.9028,50 \mathrm{ng} / \mathrm{ml}$ vs $200 \mathrm{ng} / \mathrm{ml} p=0.7275$, unpaired two-tailed $t$ test), suggesting that $50 \mathrm{ng} / \mathrm{ml}$ was the saturating concentration for white matter NG2 cells in our slice culture system. By contrast, PDGF did not significantly increase the percentage of $\mathrm{EDU}^{+} \mathrm{GFP}^{+}$cells in the neocortical gray matter regions of the same slices at all concentrations tested (Fig. 1B,E-G). There was a trend toward PDGFinduced proliferation of gray matter NG2 cells at the higher concentrations. However, these values did not reach significance over control untreated samples and were always significantly lower than those in white matter. Neither FGF2 nor EGF increased proliferation of GFP ${ }^{+} \mathrm{NG} 2$ cells in the neocortex or corpus callosum of $\mathrm{P} 8$ slices (Fig. 1C-E) but increased the number of $\mathrm{EDU}^{+} \mathrm{GFP}^{-}$cells in the subventricular zone (SVZ) (Fig. 1C,D), consistent with previously reported effects of FGF2 and EGF on SVZ cells (Naruse et al., 2006, Doetsch et al., 2002).

To determine whether the differential response of gray and white matter NG2 cells to PDGF was the result of the different degree of maturity of the cells in the two regions, we incubated forebrain slices isolated from younger (P4) NG2creBAC:ZEG mice with 10,25 , and $50 \mathrm{ng} / \mathrm{ml}$ of PDGF and compared the proliferative response between gray and white matter and to P8 slices. In slice cultures from P4 mice, as in P8 mice, NG2 cells in 

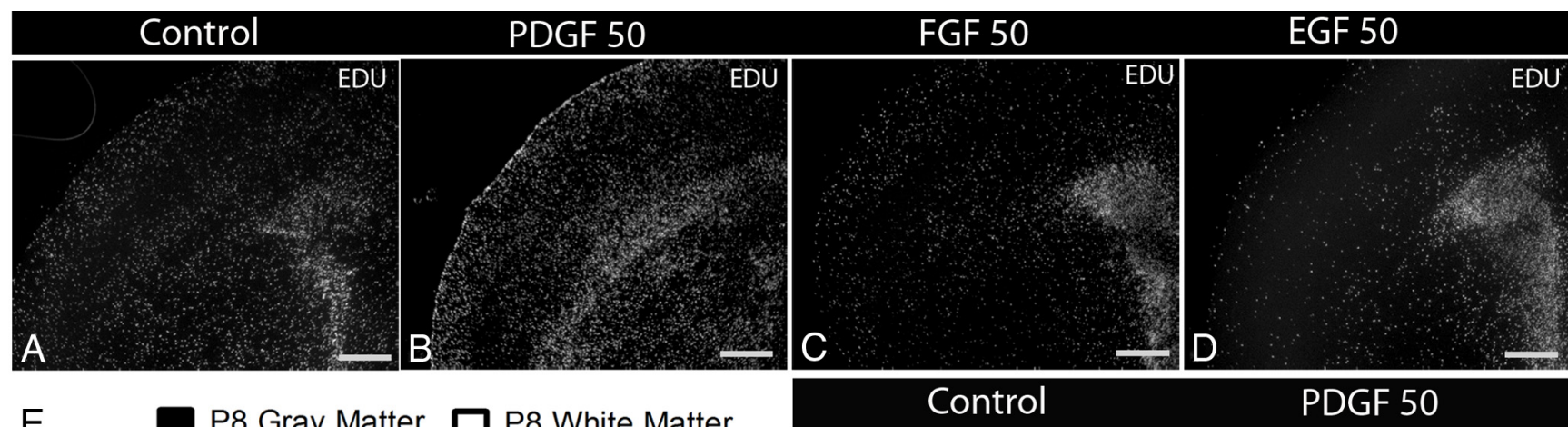

E

P8 Gray Matter

P8 White Matter
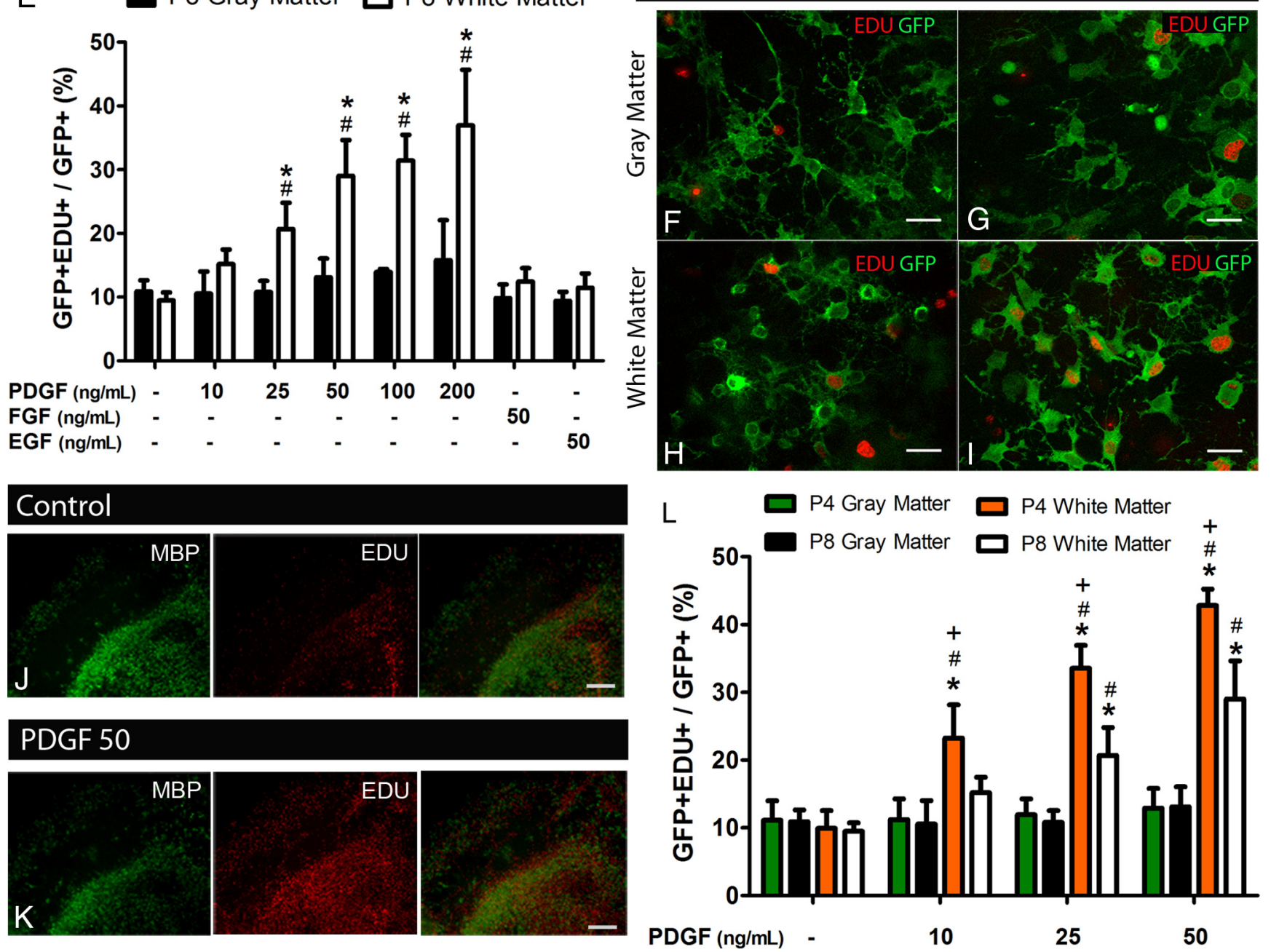

Figure 1. PDGF-induced proliferation of white matter NG2 cells in forebrain slice cultures of NG2creBAC:ZEG mice. Low-magnification images showing EDU ${ }^{+}$cells in forebrain slice cultures exposed to no growth factor $(\boldsymbol{A}), 50 \mathrm{ng} / \mathrm{ml}$ PDGF $(\boldsymbol{B})$, FGF2 ( $\left(\boldsymbol{)}\right.$, and EGF $(\boldsymbol{D})$ for $48 \mathrm{~h}$. Quantification of GFP ${ }^{+}$EDU $^{+}$cells in P8 neocortex (gray matter) and corpus callosum (white matter) after exposure to the different growth factors $(\boldsymbol{E})$ showing increased proportion of proliferating white matter GFP ${ }^{+}$cells after exposure to PDGF but not FGF2 or EGF. Dose-response to PDGF demonstrates that gray matter cells do not increase their proliferation even at and above saturating concentrations of PDGF for white matter cells. High-magnification images taken from gray $(\boldsymbol{F}, \boldsymbol{G})$ and white $(\boldsymbol{H}$, I) matter regions showing GFP fluorescence and EDU labeling in control $(\boldsymbol{F}, \boldsymbol{H})$ and PDGF-treated $(\boldsymbol{G}, \boldsymbol{I})$ slices. MBP and EDU double labeling of cortical slice cultures in control $(\boldsymbol{J})$ and after exposure to $50 \mathrm{ng} / \mathrm{ml} \mathrm{PDGF}(\boldsymbol{K})$ identifies the gray and white matter regions and demonstrates the localization of proliferating EDU ${ }^{+}$cells to white matter after PDGF exposure. Quantification of GFP ${ }^{+}$EDU ${ }^{+}$ cells in gray and white matter of forebrain slices isolated from P4 and P8 animals $(\boldsymbol{L})$ demonstrating an age-dependent differential response to PDGF by white matter NG2 cells. Scale bars: $\boldsymbol{A}-\boldsymbol{D}, \boldsymbol{J}$, $\boldsymbol{K}, 100 \mu \mathrm{m} ; \boldsymbol{F}-\boldsymbol{I}, 25 \mu \mathrm{m} .{ }^{*} p<0.001$, compared with gray matter (two-way ANOVA, Bonferroni post test). ${ }^{\#} p<0.05$, compared with same region control (two-way ANOVA, Bonferroni post test). ${ }^{+} p<0.001$, compared with P8 (two-way ANOVA, Bonferroni post test). Error bars indicate SD.

white matter exhibited more than a fourfold increase in proliferation when they were treated with $50 \mathrm{ng} / \mathrm{ml}$ PDGF, but NG2 cells in gray matter failed to proliferate in response to PDGF (Fig. $1 L$ ). Furthermore, we noted a significantly greater response to PDGF by white matter NG2 cells in slices prepared at P4 compared with P8 at all three concentrations of PDGF tested, suggesting a greater sensitivity of NG2 cells in the more immature white matter to PDGF (Fig. 1L). Therefore, the differences in proliferative response of gray and white matter NG2 cells are likely not a reflection of the degree of maturity of the cells but rather reflect a fundamental difference between gray and white matter NG2 cells or their environment. 

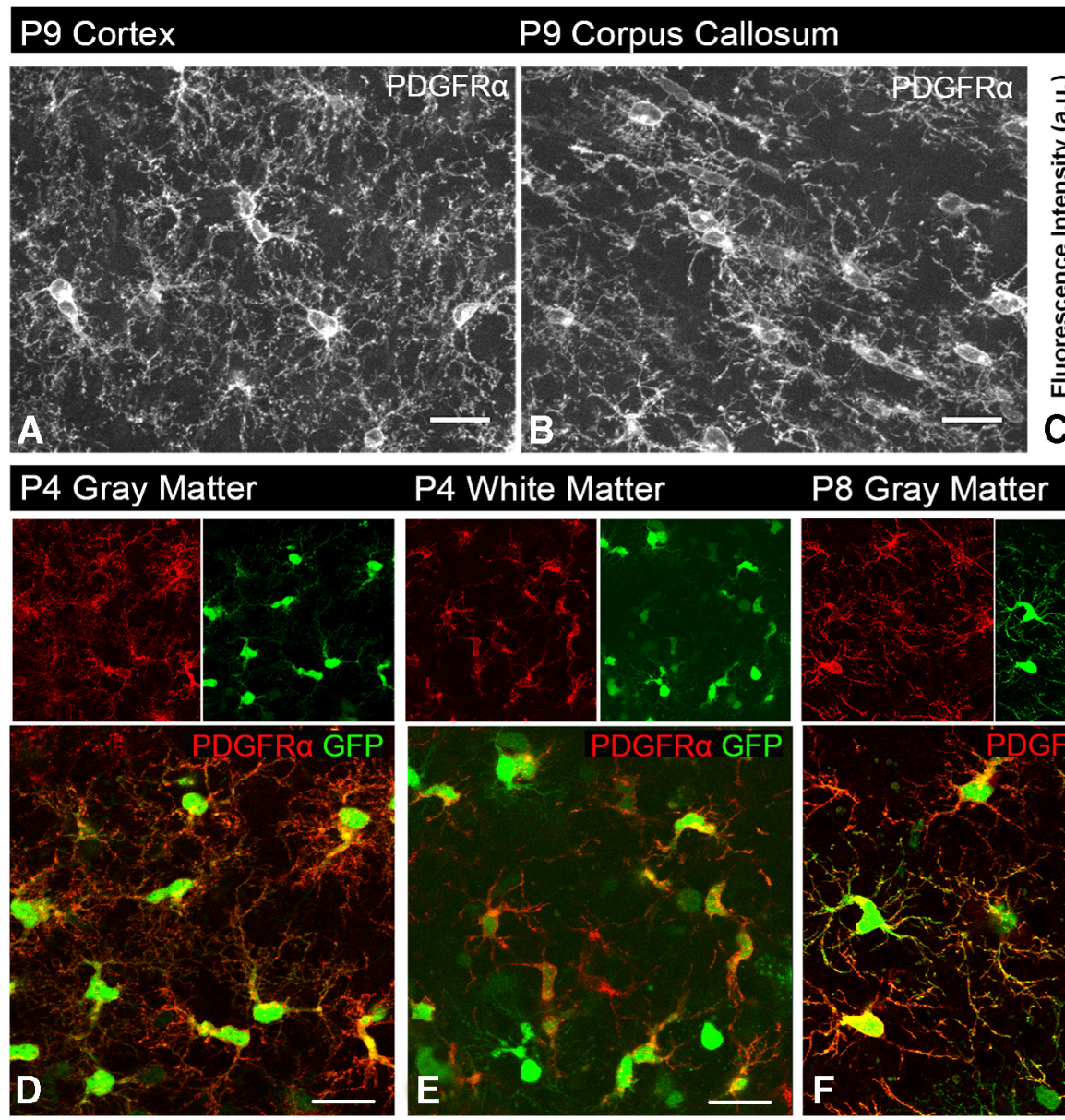

PDGFRa Fluorescence Intensity

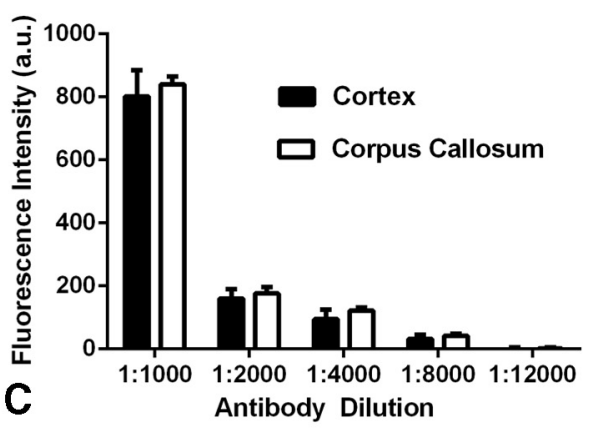

Figure 2. PDGFR $\alpha$ expression is similar between gray and white matter regions. Images taken from P9 cortex (A) and corpus callosum (B) immunolabeled for PDGFR $\alpha$. Fluorescence intensity measurements taken from both the cortex and corpus callosum at different antibody concentrations $(\boldsymbol{C})$ show similar PDGFR $\alpha$ immunofluorescence intensity in both areas, suggesting that PDGFR $\alpha$ expression is similar between gray and white matter (two-way ANOVA, Bonferroni post test). A.U., arbitrary units. Images taken from P4 (D,E) and P8 $(\boldsymbol{F}, \boldsymbol{G})$ slice cultures from gray and white matter regions of NG2creBAC:ZEG mice immunolabeled for PDGFR $\alpha$ (red), demonstrating similar expression levels of PDGFR $\alpha$ between the two regions and two ages. Green represents GFP fluorescence. Scale bars, $25 \mu \mathrm{m}$. Error bars indicate SD.

We next examined whether there was differential expression of PDGFR $\alpha$ between gray and white matter regions, which might account for the region-dependent differences in PDGF-induced proliferation. Using immunofluorescence intensity quantification, we found no significant differences in the levels of PDGFR $\alpha$ expression between NG2 cells in the corpus callosum and neocortex of coronal sections from wild-type P9 mice at all antibody concentrations tested (Fig. 2A-C). Similarly, there was no detectable difference in the level and distribution of PDGFR $\alpha$ immunofluorescence on $\mathrm{GFP}^{+} \mathrm{NG} 2$ cells in the gray and white matter of slices cultured in the absence of PDGF from P4 or P8 brain (Fig. 2D-G). The GFP ${ }^{+}$cells that lack $\operatorname{PDGFR} \alpha$ reactivity are likely to be differentiated oligodendrocytes that have downregulated PDGFR $\alpha$ expression. These observations indicate that the lack of PDGF-induced NG2 cell proliferation in gray matter cannot be attributed to the lack of PDGFR $\alpha$ expression.

To determine whether the region-dependent difference could be seen in other parts of the CNS, we examined the effects of PDGF on proliferation of NG2 cells in the gray and white matter of cerebellar slice cultures obtained from P8 mice. Basal levels of NG2 cell proliferation in the cerebellar gray and white matter were similar. Treatment with PDGF led to a 2.7-fold and 4.5-fold increase in the proportion of $\mathrm{GFP}^{+}$cells that were also $\mathrm{EDU}^{+}$in gray and white matter, respectively (Fig. 3). The proportion of
$\mathrm{EDU}^{+} \mathrm{GFP}^{+}$cells was twofold higher in the white matter than that in the gray matter after PDGF treatment. These data suggested that the observed difference in PDGF-induced proliferation between gray and white matter NG2 cells was common to both forebrain and hindbrain.

\section{Transplanted NG2 cells retain the proliferative behavior of} the site of origin

To determine whether the cellular environment was causing the higher proliferative response of white matter NG2 cells to PDGF, gray or white matter explants from P8 NG2creBAC:ZEG slices were transplanted into the cortex or corpus callosum of wild-type littermate slice cultures. Transplanted tissue pieces were allowed to integrate into the host tissue for $7 \mathrm{~d}$, and proliferation of $\mathrm{GFP}^{+}$ donor cells was examined (Fig. $4 A-M$ ).

PDGF induced a threefold to fourfold increase in proliferation of $\mathrm{GFP}^{+}$cells from both gray and white matter regardless of their location in the host slice (Fig. 4M). Compared with gray matterderived $\mathrm{GFP}^{+}$cells, however, both basal and PDGF-induced proliferation of white matter-derived $\mathrm{GFP}^{+}$cells was twofold higher (Fig. 4M). Gray matter-derived cells proliferated significantly less than white matter-derived cells even when transplanted into white matter regions in the host slice (Fig. 4J-M). Proliferation of white matter-derived NG2 cells was not reduced when transplanted into 


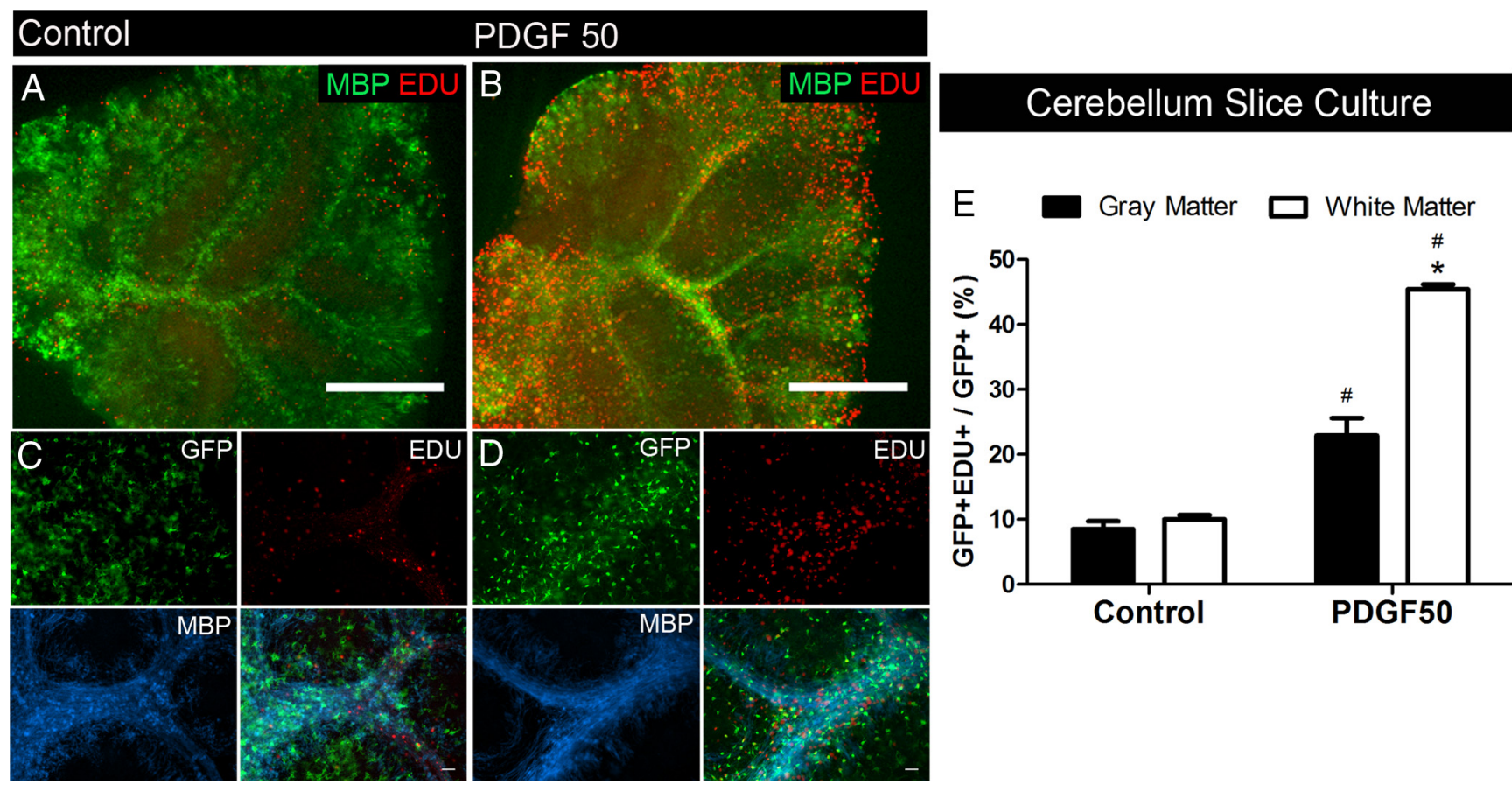

Figure 3. PDGF-induced proliferation of white matter NG2 cells in cerebellar slice cultures. Low-magnification images showing EDU ${ }^{+}$cells in the control condition $(A)$ and after $48 \mathrm{~h}$ of exposure to $50 \mathrm{ng} / \mathrm{ml} \mathrm{PDGF} \mathrm{(B).} \mathrm{MBP} \mathrm{immunolabeling} \mathrm{(green)} \mathrm{shows} \mathrm{white} \mathrm{matter.} \mathrm{Simultaneous} \mathrm{detection} \mathrm{of} \mathrm{GFP,} \mathrm{EDU,} \mathrm{and} \mathrm{MBP}(\boldsymbol{C}, \boldsymbol{D})$ showing an increase in the proportion of EDU ${ }^{+}$GFP ${ }^{+}$cells in white matter regions $\left(\mathrm{MBP}^{+}\right)$in slices exposed to PDGF (D) compared with control (C).E, Quantification showed a significant increase in the proportion of proliferating GFP ${ }^{+}$cells in both gray and white matter regions, with a greater magnitude of increase in white matter regions. Scale bars: $A, B, 100 \mu \mathrm{m} ; \boldsymbol{C}, \boldsymbol{D}, 25 \mu \mathrm{m} .{ }^{*} p<0.01$, compared with gray matter (two-way ANOVA, Bonferroni post test). $\# p<0.01$, compared with same region control (two-way ANOVA, Bonferroni post test). Error bars indicate SD.

gray matter regions of the host slice (Fig. $4 A-C, M$ ). These data suggest that NG2 cells in the white matter have an intrinsically higher proliferative capacity than those in gray matter.

To further test this, $300 \mu \mathrm{m}^{3}$ explants from gray and white matter were isolated and directly cultured on Millicell inserts for $7 \mathrm{~d}$, and proliferation of $\mathrm{GFP}^{+}$cells was assayed as above after exposure to PDGF, FGF2, or EGF for $48 \mathrm{~h}$. White matter-derived NG2 cells increased their proliferation by 3.1- and 4.1-fold in response to $25 \mathrm{ng} / \mathrm{ml}$ and $50 \mathrm{ng} / \mathrm{ml}$ PDGF, respectively (Fig. $4 N$ ). By contrast, proliferation of NG2 cells from the gray matter did not increase after PDGF treatment (Fig. 4N). Neither FGF2 nor EGF had any effect on proliferation of NG2 cells from gray or white matter (Fig. $4 N$ ). These observations further supported the previous findings suggesting an intrinsically greater proliferative capacity of NG2 cells in white matter.

\section{NG2 cell proliferation is regulated by the PI-3 kinase/mTOR and $\mathrm{Wnt} / \boldsymbol{\beta}$-catenin pathways}

To determine whether there were intrinsic differences in the signal transduction mechanism between NG2 cells in gray and white matter, we examined the effects of pharmacological agents on NG2 cell proliferation using isolated explant cultures and forebrain slices from P8 NG2creBAC:ZEG mice. The agents were added during the last $48 \mathrm{~h}$ of culture, concomitant with PDGF. The specific ERK1/2 inhibitors U0126 and PD98059 had no effect on proliferation of NG2 cells from gray or white matter in the presence or absence of PDGF (Fig. $5 A, B$ ). Incubation of explants with $20 \mu \mathrm{M}$ U0126 caused a $67 \%$ reduction in the level of phosphorylated p $44 / 42$ Erk1/2 when normalized to total p44/42 Erk1/2 signal (Fig. $5 \mathrm{H}$, left). These data indicate that Erk1/2 is not involved in mediating the proliferative response of NG2 cells to PDGF.

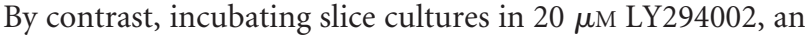
inhibitor of PI3K, reduced the level of phosphorylation of Akt on
S473 by 70\% in PDGF-treated cultures (Fig. $5 \mathrm{H}$, right) and decreased PDGF-induced proliferation of NG2 cells in the white matter by $65 \%$. Similarly, $20 \mu \mathrm{M}$ LY 294002 decreased basal NG2 cell proliferation in the white matter by $57 \%$ and NG2 cell proliferation in the gray matter under basal and PDGF-treated conditions by $89 \%$ and $88 \%$, respectively (Fig. 5 C). Inhibition of NG2 cell proliferation was also seen in both gray and white matter by another PI3K inhibitor, wortmannin (Fig. 5D). The mTOR is a known target of activated Akt. There was a significant inhibition of basal and PDGF-induced NG2 cell proliferation in both gray and white matter by the mTOR inhibitor rapamycin at 50 and 100 nм (Fig. 5E).

The Wnt pathway has been shown to be activated by PDGF in NG2 cells (Chew et al., 2011). To determine whether the canonical Wnt pathway contributes to NG2 cell proliferation, slice cultures were incubated in the presence of XAV939, which stabilizes Axin by inhibiting tankyrase and thereby inhibits nuclear accumulation of $\beta$-catenin (Huang et al., 2009). Treatment with 1-50 $\mu \mathrm{M}$ XAV939 significantly inhibited PDGF-induced proliferation in white matter in a dose-dependent manner (Fig. $5 F$ ), with $51 \%$ inhibition attained with $50 \mu \mathrm{M}$ XAV939. When $50 \mu \mathrm{M}$ XAV939 was added to the slices together with $20 \mu \mathrm{M}$ LY294002 or $100 \mathrm{nM}$ rapamycin in the presence of PDGF, there was a further reduction in the proliferation of NG2 cells, although it remained slightly above basal levels (Fig. 5G). Collectively, these data suggest that NG2 cell proliferation is largely mediated by a combination of the $\mathrm{PI} 3 \mathrm{~K} / \mathrm{mTOR}$ and $\mathrm{Wnt} / \beta$-catenin signaling pathways.

\section{Discussion}

Using organotypic slice culture system, we have demonstrated that NG2 cells in white matter exhibited a threefold to fourfold greater proliferative response to PDGF than those in gray matter. The greater proliferative response of white matter NG2 cells was 


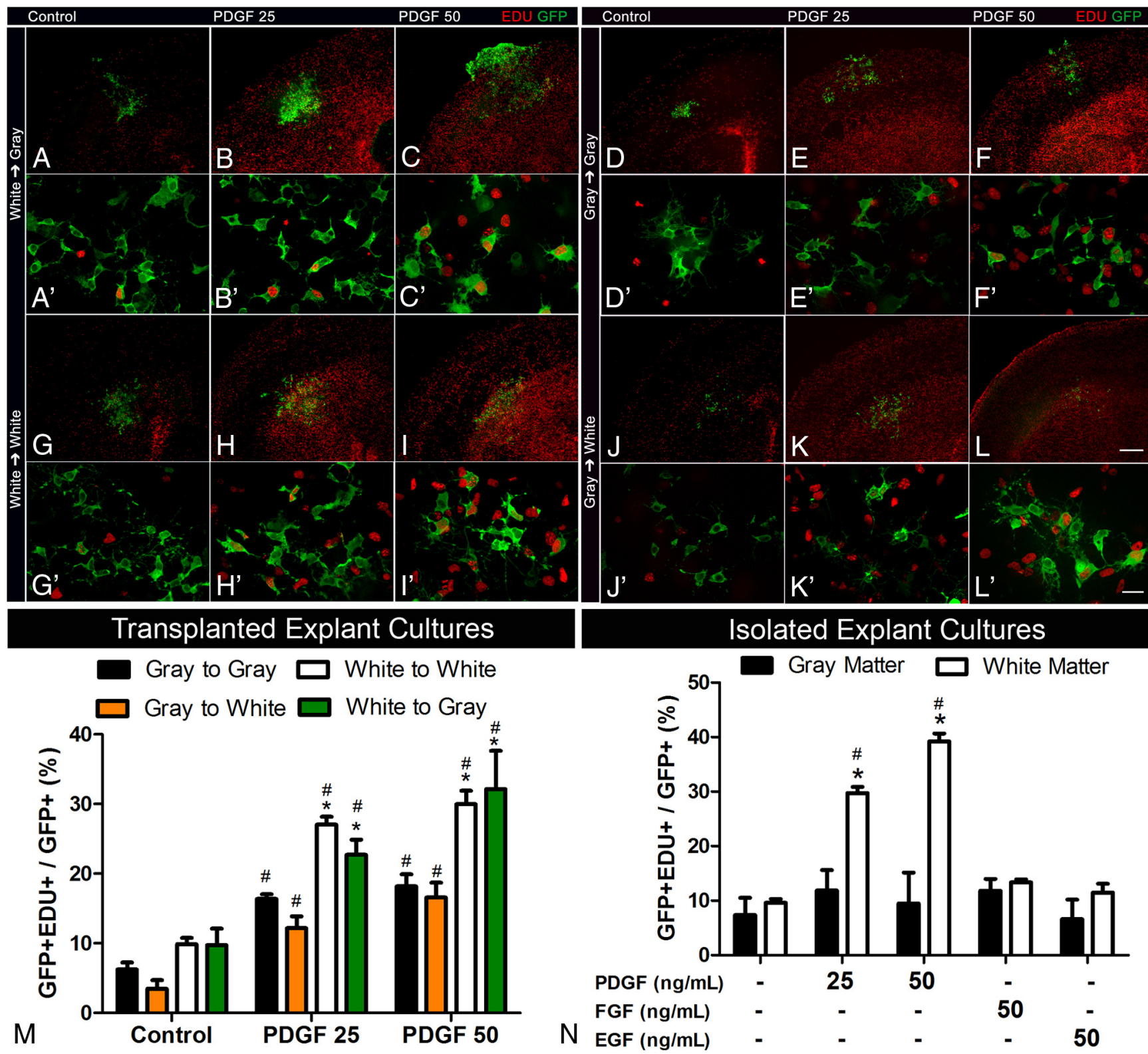

Figure 4. NG2 cell proliferation in transplanted and isolated explants. Representative low- $(\boldsymbol{A}-\boldsymbol{L})$ and high-magnification $\left(\boldsymbol{A}^{\prime}-\boldsymbol{L}^{\prime}\right)$ images of gray or white matter explants taken from NG2creBAC:ZEG mice and transplanted to gray or white matter regions of wild-type littermate slice cultures. Quantification of transplanted cells $(\boldsymbol{M})$ shows a greater increase in the proportion of $\mathrm{GFP}^{+}$cells that were EDU ${ }^{+}$originating from the white matter explants when exposed to $25 \mathrm{ng} / \mathrm{ml}$ and $50 \mathrm{ng} / \mathrm{ml}$ PDGF. Quantification of isolated explants from gray and white matter (N) showed significant increases in the proportion of proliferating GFP ${ }^{+}$cells only in white matter explants exposed to PDGF but not FGF2 or EGF. Scale bars: $A-L, 100 \mu \mathrm{m} ; A^{\prime}-L^{\prime}, 25 \mu \mathrm{m}$. ${ }^{*} p<0.01$, compared with gray matter (two-way ANOVA, Bonferroni post test). ${ }^{~} p<0.01$, compared with same region control (two-way ANOVA, Bonferroni post test). Error bars indicate SD.

specific to PDGF, as these cells did not proliferate significantly in response to EGF or FGF2, which is consistent with the observations that NG2 cells are distinct from EGF- and FGF2-responsive cells in the SVZ (Chojnacki et al., 2008; Komitova et al., 2009; Ortega et al., 2013). The greater response of white matter NG2 cells to PDGF was not the result of measurable differences in the level of PDGFR $\alpha$ expression in gray and white matter, consistent with previous reports of PDGFR $\alpha$ expression (Pringle et al., 1992; Nishiyama et al., 1996; Rivers et al., 2008). Furthermore, we found that white matter NG2 cells in slices isolated from P4 animals proliferated in response to lower concentrations of PDGF and to a greater extent than P8 white matter cells.

The difference in the response between $\mathrm{P} 4$ and $\mathrm{P} 8$ white matter NG2 cells is intriguing considering the in vivo observation of the dramatic decrease in proliferative rate of NG2 cells in the spinal cord from ages P10 to P18 (Bu et al., 2004). The slices were cultured for $7 \mathrm{~d}$ before they were exposed to growth factors. Therefore, P4 slices could be considered analogous to P13 in vivo, whereas P8 slices could be considered P17 at the time of EDU administration and analysis. It is possible that the decline in proliferation in the third postnatal week documented in vivo could be accounted for by a decline in the ability of the cells to respond to PDGF. These observations suggest that there are age-dependent mechanisms that lead to decreased sensitivity of white matter cells to PDGF, in addition to the limiting supply of PDGF that occurs with the expansion of NG2 cells (Calver et al., 1998). Because organotypic slice cultures from adult brain do not survive as well as perinatal slices, we were unable to test whether a similar regional heterogeneity in proliferative response to PDGF exists in the adult CNS. It has been shown that embryonic human neural progenitor cells proliferate at a higher rate in response to 

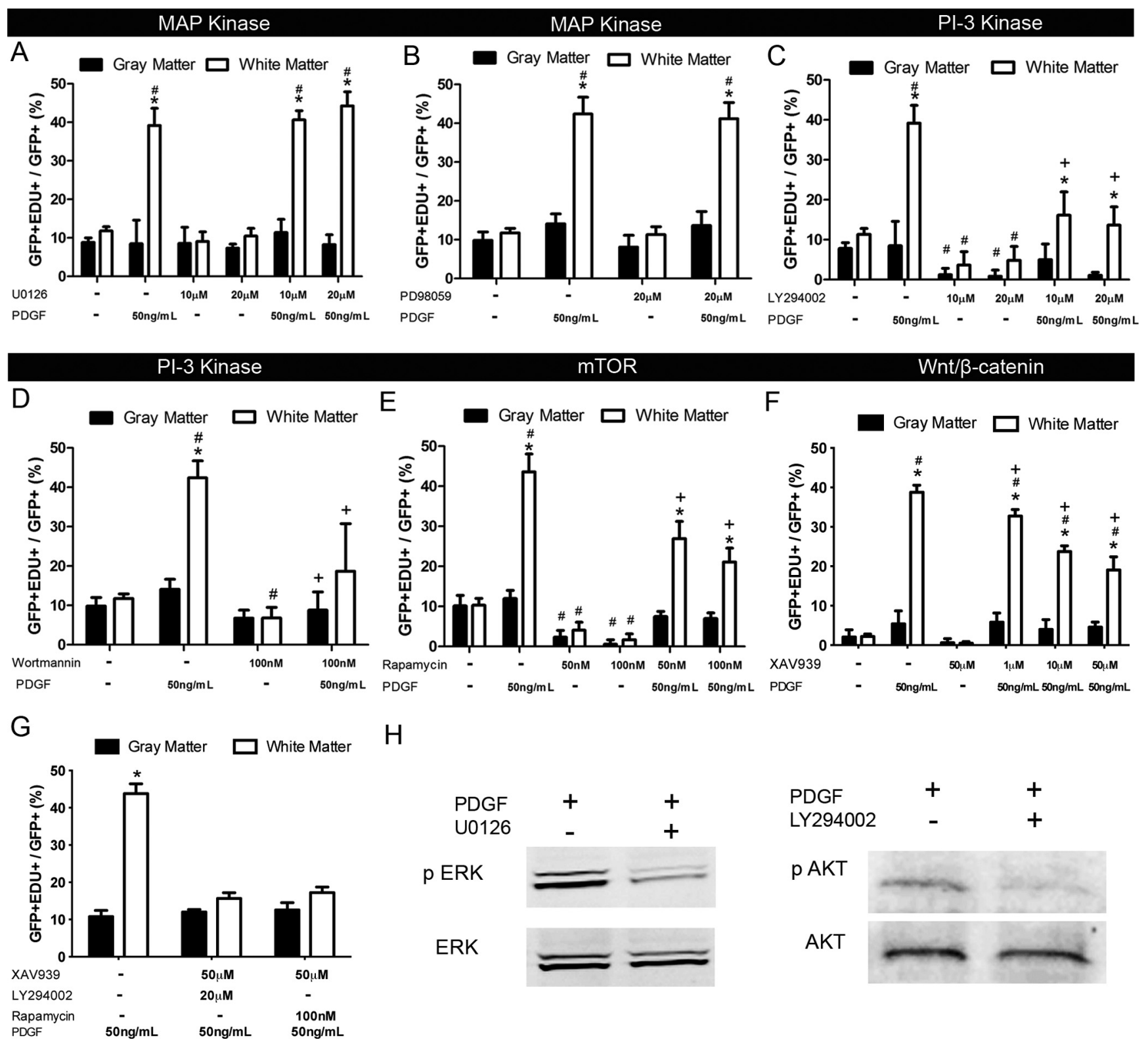

$\mathrm{H}$
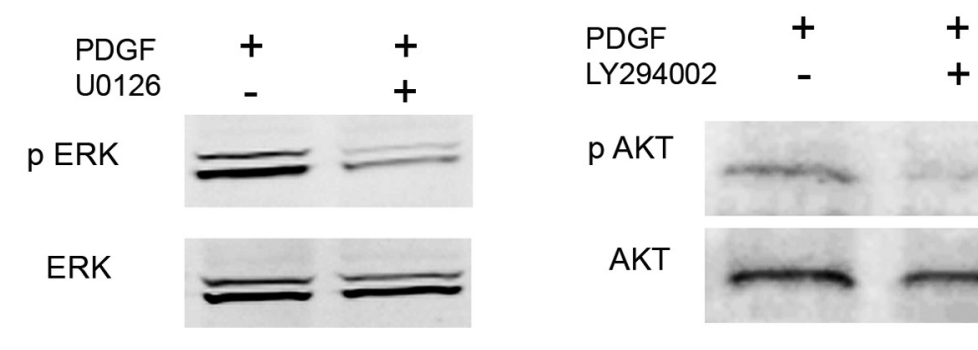

p AKT

AKT

Figure 5. Basal and PDGF-induced proliferation of gray and white matter NG2 cells is dependent on the PI3K-mTOR and Wnt/ $\beta$-catenin pathways. Quantification of slices exposed to the ERK1/2 inhibitors U0126 (A) and PD98059 (B) showed no change in the proportion of GFP ${ }^{+}$cells that were EDU ${ }^{+}$with or without PDGF. Quantification of slices exposed to PI3K inhibitors LY294002 ( $($) and wortmannin $(\boldsymbol{D})$, the mTOR inhibitor rapamycin $(\boldsymbol{E})$, and the tankyrase inhibitor XAV939 $(\boldsymbol{F})$ showed a significant decrease in the proportion of GFP ${ }^{+}$cells that were EDU ${ }^{+}$in both gray and white matter, even when exposed to PDGF. G, Quantification of slices exposed to XAV939 and either LY294002 or rapamycin further reduced PDGF-induced proliferation in white matter close to the basal level. $\boldsymbol{H}$, Representative Western blots showing effective inhibition of p44/42 MAPK ERK1/2 phosphorylation by U0126 and Akt $\$ 473$ phosphorylation by LY294002 in slice cultures in the presence of PDGF. ${ }^{*} p<0.001$, compared with gray matter (two-way ANOVA, Bonferroni post test). ${ }^{\#}<<0.05$, compared with same region control without PDGF (two-way ANOVA, Bonferroni post test). ${ }^{+} p<0.05$, compared with $50 \mathrm{ng} / \mathrm{ml}$ PDGF only (two-way ANOVA, Bonferroni post test). Error bars indicate SD.

PDGF and FGF2 (Chojnacki et al., 2008) and undergo greater expansion after transplantation compared with adult-derived neural progenitors (Windrem et al., 2004). Thus, it is possible that the difference in PDGF-induced proliferation between gray and white matter is more pronounced in the young CNS.

The difference in the response of gray and white matter NG2 cells to PDGF could be the result of cell intrinsic or environmental mechanisms. Our finding from slice transplant experiments that the proliferative response to PDGF was not influenced by the location in the host slice suggests cell intrinsic mechanisms, although there may be differences in the local microenvironment immediately surrounding NG2 cells in gray and white matter. In the embryonic spinal cord, mRNA encoding PDGF-A is more abundant in the gray matter
(Calver et al., 1998), which may lead to desensitization of the receptor. However, this is unlikely in the postnatal brain because heterotopic transplants behaved similarly to the cells at the site of origin in the presence or absence of PDGF. Thus, it is likely that NG2 cell response to PDGF is determined either cell intrinsically or very locally by surrounding cells and not by mechanisms involving rapid diffusion or signals from intact axons.

In some of the experiments described here, a higher concentration of PDGF was used than the standard $10 \mathrm{ng} / \mathrm{ml}$ known to cause a maximum proliferative response in dissociated NG2 cell cultures (Barres et al., 1993). The higher concentration required for a consistent proliferative response in our slice cultures may be the result of limited diffusion of the growth factor through the 
tissue in the slices. However, we think this is unlikely, as we have seen a dose-dependent increase in the percentage of proliferating cells in dissociated NG2 cell cultures with PDGF concentrations ranging from 1 to $50 \mathrm{ng} / \mathrm{ml}$ (L. Boshans, K. Patel, and A. Nishiyama, unpublished observations). Even at PDGF concentrations that were 2-4 times higher than the saturating concentrations for white matter cells, gray matter NG2 cells failed to proliferate, indicating that PDGF penetration into the slice was not the major factor contributing to the region-dependent differences.

Pharmacological inhibition of Erk1/2 activation had no effect on basal or PDGF-induced NG2 cell proliferation despite the ability of the inhibitor to reduce phosphorylation of Erk1/2 in PDGF-treated slices. Earlier studies using dissociated NG2 cells revealed a significant reduction in PDGF-induced proliferation by ERK inhibitors (Baron et al., 2000), and genetic deletion of Erk1/2 in Olig2-expressing cells reduced NG2 cell proliferation in early postnatal spinal cord (Newbern et al., 2011). By contrast, conditional Erk2 knock-out in oligodendrocyte lineage cells had no effect on NG2 cell proliferation even in Erk1 null background (Fyffe-Maricich et al., 2011; Ishii et al., 2012), which is consistent with our observations. These conflicting findings may be the result of differences in culture conditions, postnatal age, CNS regions examined, and/or the stage of maturity at which Erk2 was deleted (Ishii et al., 2013). It is possible that MAPK plays a more important role in immature progenitor cells than in NG2 cells.

In our slice cultures, inhibitors of PI3K almost completely abolished basal proliferation of gray and white matter NG2 cells and partially inhibited PDGF-induced proliferation of white matter NG2 cells. Akt and mTOR complex have been implicated in terminal oligodendrocyte differentiation and myelination but not in NG2 cell proliferation (Flores et al., 2008; Narayanan et al., 2009; Tyler et al., 2009). By contrast, other studies have shown a critical role for PI3K in both basal and PDGF-induced NG2 cell proliferation (Ebner et al., 2000; Baron et al., 2002). Furthermore, inhibiting $\mathrm{mTOR}$ with a rapamycin analog has been shown to inhibit proliferation of PDGF-induced gliomas in mice (Uhrbom et al., 2004). We have found that treatment of the slice cultures with rapamycin produced a similar effect to PI3K inhibitors, suggesting that the Akt-mTOR pathway is a predominant signaling mechanism for basal and PDGF-induced proliferation of NG2 cells. The lack of effect of rapamycin or constitutively active Akt on NG2 cell numbers reported in previous studies (Flores et al., 2008; Tyler et al., 2009) could be the result of the difference in the maturational stage of target cells.

Our findings that the tankyrase inhibitor XAV939 inhibits NG2 cell proliferation suggest that the Wnt/ $\beta$-catenin pathway plays a significant role in basal and PDGF-dependent NG2 cell proliferation. This is consistent with the findings by Azim and Butt (2011) who showed increased NG2 cell expansion after intraventricular injection of GSK3 inhibitors, and the observation that the Wnt pathway is activated by PDGF in dissociated cultures of NG2 cells (Chew et al., 2011). The Wnt- $\beta$-catenin pathway has also been shown to inhibit oligodendrocyte maturation (Fancy et al., 2009; Feigenson et al., 2009; Ye et al., 2009). Additional mechanisms, such as activation of phospholipase $\mathrm{C} \gamma$ (McKinnon et al., 2005) and the p38 MAPK pathway (Baron et al., 2000), may account for the residual NG2 cell proliferation that was not abolished by simultaneously inhibiting $\beta$-catenin and PI3K or mTOR.

The pharmacological experiments described above suggest that NG2 cells in gray and white matter use similar intracellular signal transduction pathways to mediate their proliferation. It is possible that the regional difference in NG2 cell proliferation to PDGF could be the result of differences in the intracellular redox state (Smith et al., 2000; Power et al., 2002). Electrophysiological mechanisms could also contribute to the difference in the proliferative behavior of NG2 cells in gray and white matter. For example, potassium channels are known to regulate the proliferative capacity of NG2 cells (Gallo et al., 1996; Vautier et al., 2004), are influenced by PDGFR $\alpha$ activation (Chittajallu et al., 2005), and are present at a higher density in the corpus callosum compared with the neocortex (Chittajallu et al., 2004).

We have demonstrated for the first time in an intact culture system that white matter NG2 cells undergo a greater proliferative response to PDGF than gray matter NG2 cells. Rapidly proliferating NG2 cells have been shown to generate myelinating oligodendrocytes more readily than those with lower proliferation rates (Bouslama-Ourghlani et al., 2005; Irvine and Blakemore, 2007). The greater proliferative response of white matter NG2 cells to PDGF may be linked to their ability to differentiate into myelinating oligodendrocytes. It would be interesting to determine whether the highly myelinogenic function of PDGFR $\alpha / \mathrm{CD} 140 \mathrm{a}^{+}$cells isolated from human fetal forebrain could be attributed to a subpopulation of cells originating from the nascent white matter tracts (Sim et al., 2011). Further understanding of the mechanisms underlying the regional differences in PDGF-induced NG2 cell proliferation could lead to novel strategies for myelin repair.

\section{References}

Albert M, Antel J, Brück W, Stadelmann C (2007) Extensive cortical remyelination in patients with chronic multiple sclerosis. Brain Pathol 17:129138. CrossRef Medline

Azim K, Butt AM (2011) GSK3beta negatively regulates oligodendrocyte differentiation and myelination in vivo. Glia 59:540-553. CrossRef Medline

Bahr BA, Kessler M, Rivera S, Vanderklish PW, Hall RA, Mutneja MS, Gall C, Hoffman KB (1995) Stable maintenance of glutamate receptors and other synaptic components in long-term hippocampal slices. Hippocampus 5:425-439. CrossRef Medline

Baron W, Metz B, Bansal R, Hoekstra D, de Vries H (2000) PDGF and FGF-2 signaling in oligodendrocyte progenitor cells: regulation of proliferation and differentiation by multiple intracellular signaling pathways. Mol Cell Neurosci 15:314-329. CrossRef Medline

Baron W, Shattil SJ, ffrench-Constant C (2002) The oligodendrocyte precursor mitogen PDGF stimulates proliferation by activation of alpha(v) beta3 integrins. EMBO J 21:1957-1966. CrossRef Medline

Barres BA, Schmid R, Sendtner M, Raff MC (1993) Multiple extracellular signals are required for long-term oligodendrocyte survival. Development 118:283-295. CrossRef Medline

Bouslama-Oueghlani L, Wehrlé R, Sotelo C, Dusart I (2005) Heterogeneity of NG2-expressing cells in the newborn mouse cerebellum. Dev Biol 285: 409-421. CrossRef Medline

Bu J, Banki A, Wu Q, Nishiyama A (2004) Increased NG2(+) glial cell proliferation and oligodendrocyte generation in the hypomyelinating mutant shiverer. Glia 48:51-63. CrossRef Medline

Calver AR, Hall AC, Yu WP, Walsh FS, Heath JK, Betsholtz C, Richardson WD (1998) Oligodendrocyte population dynamics and the role of PDGF in vivo. Neuron 20:869-882. CrossRef Medline

Chew LJ, Shen W, Ming X, Senatorov VV Jr, Chen HL, Cheng Y, Hong E, Knoblach S, Gallo V (2011) SRY-box containing gene 17 regulates the $\mathrm{Wnt} / \beta$-catenin signaling pathway in oligodendrocyte progenitor cells. J Neurosci 31:13921-13935. CrossRef Medline

Chittajallu R, Aguirre A, Gallo V (2004) NG2-positive cells in the mouse white and grey matter display distinct physiological properties. J Physiol 561:109-122. CrossRef Medline

Chittajallu R, Aguirre AA, Gallo V (2005) Downregulation of plateletderived growth factor-alpha receptor-mediated tyrosine kinase activity as a cellular mechanism for $\mathrm{K}+$-channel regulation during oligodendrocyte development in situ. J Neurosci 25:8601-8610. CrossRef Medline

Chojnacki A, Kelly JJ, Hader W, Weiss S (2008) Distinctions between fetal 
and adult human platelet-derived growth factor-responsive neural precursors. Ann Neurol 64:127-142. CrossRef Medline

Dawson MR, Polito A, Levine JM, Reynolds R (2003) NG2-expressing glial progenitor cells: an abundant and widespread population of cycling cells in the adult rat CNS. Mol Cell Neurosci 24:476-488. CrossRef Medline

Dimou L, Simon C, Kirchhoff F, Takebayashi H, Gotz M (2008) Progeny of Olig2-expressing progenitors in the gray and white matter of the adult mouse cerebral cortex. J Neurosci 28:10434-10442. CrossRef Medline

Doetsch F, Petreanu L, Caille I, Garcia-Verdugo JM, Alvarez-Buylla A (2002) EGF converts transit-amplifying neurogenic precursors in the adult brain into multipotent stem cells. Neuron 36:1021-1034. CrossRef Medline

Ebner S, Dunbar M, McKinnon RD (2000) Distinct roles for PI3K in proliferation and survival of oligodendrocyte progenitor cells. J Neurosci Res 62:336-345. CrossRef Medline

Fancy SP, Baranzini SE, Zhao C, Yuk DI, Irvine KA, Kaing S, Sanai N, Franklin RJ, Rowitch DH (2009) Dysregulation of the wnt pathway inhibits timely myelination and remyelination in the mammalian CNS. Genes Dev 23:1571-1585. CrossRef Medline

Feigenson K, Reid M, See J, Crenshaw EB 3rd, Grinspan JB (2009) Wnt signaling is sufficient to perturb oligodendrocyte maturation. Mol Cell Neurosci 42:255-265. CrossRef Medline

Flores AI, Narayanan SP, Morse EN, Shick HE, Yin X, Kidd G, Avila RL, Kirschner DA, Macklin WB (2008) Constitutively active akt induces enhanced myelination in the CNS. J Neurosci 28:7174-7183. CrossRef Medline

Fruttiger M, Karlsson L, Hall AC, Abramsson A, Calver AR, Boström H, Willetts K, Bertold CH, Heath JK, Betsholtz C, Richardson WD (1999) Defective oligodendrocyte development and severe hypomyelination in PDGF-A knockout mice. Development 126:457-467. Medline

Fyffe-Maricich SL, Karlo JC, Landreth GE, Miller RH (2011) The ERK2 mitogen-activated protein kinase regulates the timing of oligodendrocyte differentiation. J Neurosci 31:843-850. CrossRef Medline

Gallo V, Zhou JM, McBain CJ, Wright P, Knutson PL, Armstrong RC (1996) Oligodendrocyte progenitor cell proliferation and lineage progression are regulated by glutamate receptor-mediated $\mathrm{K}+$ channel block. J Neurosci 16:2659-2670. Medline

Hill RA, Natsume R, Sakimura K, Nishiyama A (2011) NG2 cells are uniformly distributed and NG2 is not required for barrel formation in the somatosensory cortex. Mol Cell Neurosci 46:689-698. CrossRef Medline

Huang SM, Mishina YM, Liu S, Cheung A, Stegmeier F, Michaud GA, Charlat O, Wiellette E, Zhang Y, Wiessner S, Hild M, Shi X, Wilson CJ, Mickanin C, Myer V, Fazal A, Tomlinson R, Serluca F, Shao W, Cheng H, et al. (2009) Tankyrase inhibition stabilizes axin and antagonizes Wnt signalling. Nature 461:614-620. CrossRef Medline

Irvine KA, Blakemore WF (2007) A different regional response by mouse oligodendrocyte progenitor cells (OPCs) to high-dose X-irradiation has consequences for repopulating OPC-depleted normal tissue. Eur J Neurosci 25:417-424. CrossRef Medline

Ishii A, Fyffe-Maricich SL, Furusho M, Miller RH, Bansal R (2012) ERK1/ ERK2 MAPK signaling is required to increase myelin thickness independent of oligodendrocyte differentiation and initiation of myelination. J Neurosci 32:8855-8864. CrossRef Medline

Ishii A, Furusho M, Bansal R (2013) Sustained activation of ERK1/2 MAPK in oligodendrocytes and Schwann cells enhances myelin growth and stimulates oligodendrocyte progenitor expansion. J Neurosci 33:175-186. CrossRef Medline

Kang SH, Fukaya M, Yang JK, Rothstein JD, Bergles DE (2010) $\mathrm{NG}^{2+} \mathrm{CNS}$ glial progenitors remain committed to the oligodendrocyte lineage in postnatal life and following neurodegeneration. Neuron 68:668-681. CrossRef Medline

Komitova M, Zhu X, Serwanski DR, Nishiyama A (2009) NG2 cells are distinct from neurogenic cells in the subventricular zone. J Comp Neurol 512:702-716. CrossRef Medline

McKinnon RD, Waldron S, Kiel ME (2005) PDGF $\alpha$-receptor signal strength controls an RTK rheostat that integrates phosphoinositol 3'kinase and phospholipase $c \gamma$ pathways during oligodendrocyte maturation. J Neurosci 25:3499-3508. CrossRef Medline

Narayanan SP, Flores AI, Wang F, Macklin WB (2009) Akt signals through the mammalian target of rapamycin pathway to regulate CNS myelination. J Neurosci 29:6860-6870. CrossRef Medline

Naruse M, Nakahira E, Miyata T, Hitoshi S, Ikenaka K, Bansal R (2006) Induction of oligodendrocyte progenitors in dorsal forebrain by intraven- tricular microinjection of FGF-2. Dev Biol 297:262-273. CrossRef Medline

Newbern JM, Li X, Shoemaker SE, Zhou J, Zhong J, Wu Y, Bonder D, Hollenback S, Coppola G, Geschwind DH, Landreth GE, Snider WD (2011) Specific functions for ERK/MAPK signaling during PNS development. Neuron 69:91-105. CrossRef Medline

Nishiyama A, Lin XH, Giese N, Heldin CH, Stallcup WB (1996) Colocalization of NG2 proteoglycan and PDGF alpha-receptor on O2A progenitor cells in the developing rat brain. J Neurosci Res 43:299-314. CrossRef Medline

Nishiyama A, Komitova M, Suzuki R, Zhu X (2009) Polydendrocytes (NG2 cells): multifunctional cells with lineage plasticity. Nat Rev Neurosci 10: 9-22. CrossRef Medline

Noble M, Murray K, Stroobant P, Waterfield MD, Riddle P (1988) Plateletderived growth factor promotes division and motility and inhibits premature differentiation of the oligodendrocyte/type-2 astrocyte progenitor cell. Nature 333:560-562. CrossRef Medline

Novak A, Guo C, Yang W, Nagy A, Lobe CG (2000) Z/EG, a double reporter mouse line that expresses enhanced green fluorescent protein upon cremediated excision. Genesis 28:147-155. CrossRef Medline

Ortega F, Gascón S, Masserdotti G, Deshpande A, Simon C, Fischer J, Dimou L, Chichung Lie D, Schroeder T, Berninger B (2013) Oligodendrogliogenic and neurogenic adult subependymal zone neural stem cells constitute distinct lineages and exhibit differential responsiveness to Wnt signalling. Nat Cell Biol 15:602-613. CrossRef Medline

Power J, Mayer-Pröschel M, Smith J, Noble M (2002) Oligodendrocyte precursor cells from different brain regions express divergent properties consistent with the differing time courses of myelination in these regions. Dev Biol 245:362-375. CrossRef Medline

Pringle NP, Mudhar HS, Collarini EJ, Richardson WD (1992) PDGF receptors in the rat CNS: during late neurogenesis, PDGF alpha-receptor expression appears to be restricted to glial cells of the oligodendrocyte lineage. Development 115:535-551. Medline

Raff MC, Lillien LE, Richardson WD, Burne JF, Noble MD (1988) Plateletderived growth factor from astrocytes drives the clock that times oligodendrocyte development in culture. Nature 333:562-565. CrossRef Medline

Richardson WD, Pringle N, Mosley MJ, Westermark B, Dubois-Dalcq M (1988) A role for platelet-derived growth factor in normal gliogenesis in the central nervous system. Cell 53:309-319. CrossRef Medline

Rivers LE, Young KM, Rizzi M, Jamen F, Psachoulia K, Wade A, Kessaris N, Richardson WD (2008) PDGFRA/NG2 glia generate myelinating oligodendrocytes and piriform projection neurons in adult mice. Nat Neurosci 11:1392-1401. CrossRef Medline

Sim FJ, McClain CR, Schanz SJ, Protack TL, Windrem MS, Goldman SA (2011) CD140a identifies a population of highly myelinogenic, migration-competent and efficiently engrafting human oligodendrocyte progenitor cells. Nat Biotechnol 29:934-941. CrossRef Medline

Smith J, Ladi E, Mayer-Proschel M, Noble M (2000) Redox state is a central modulator of the balance between self-renewal and differentiation in a dividing glial precursor cell. Proc Natl Acad Sci U S A 97:10032-10037. CrossRef Medline

Stadelmann C, Albert M, Wegner C, Brück W (2008) Cortical pathology in multiple sclerosis. Curr Opin Neurol 21:229-234. CrossRef Medline

Tyler WA, Gangoli N, Gokina P, Kim HA, Covey M, Levison SW, Wood TL (2009) Activation of the mammalian target of rapamycin (mTOR) is essential for oligodendrocyte differentiation. J Neurosci 29:6367-6378. CrossRef Medline

Uhrbom L, Nerio E, Holland EC (2004) Dissecting tumor maintenance requirements using bioluminescence imaging of cell proliferation in a mouse glioma model. Nat Med 10:1257-1260. CrossRef Medline

Vautier F, Belachew S, Chittajallu R, Gallo V (2004) Shaker-type potassium channel subunits differentially control oligodendrocyte progenitor proliferation. Glia 48:337-345. CrossRef Medline

Windrem MS, Nunes MC, Rashbaum WK, Schwartz TH, Goodman RA, McKhann G 2nd, Roy NS, Goldman SA (2004) Fetal and adult human oligodendrocyte progenitor cell isolates myelinate the congenitally dysmyelinated brain. Nat Med 10:93-97. CrossRef Medline

Ye F, Chen Y, Hoang T, Montgomery RL, Zhao XH, Bu H, Hu T, Taketo MM, van Es JH, Clevers H, Hsieh J, Bassel-Duby R, Olson EN, Lu QR (2009) $\mathrm{HDAC} 1$ and HDAC2 regulate oligodendrocyte differentiation by disrupt- 
ing the $\beta$-catenin-TCF interaction. Nat Neurosci 12:829-838. CrossRef Medline

Zhu X, Bergles DE, Nishiyama A (2008) NG2 cells generate both oligodendrocytes and gray matter astrocytes. Development 135:145-157. CrossRef Medline
Zhu X, Hill RA, Dietrich D, Komitova M, Suzuki R, Nishiyama A (2011) Age-dependent fate and lineage restriction of single NG2 cells. Development 138:745-753. CrossRef Medline 